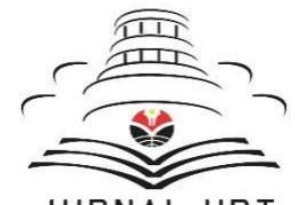

THE JOURNAL GASTRONOMY TOURISM

Volume 7 Issue 1, June 2020, 38-47

Available online at:

https://ejournal.upi.edu/index.php/gastur

\title{
Variations of Malangbong-Garut Ladu Product
}

\author{
Christian H. Rumayar ${ }^{1}$, Raissa ${ }^{2}$ \\ ${ }^{1}$ Akademi Pariwisata NHI Bandung, Bandung 40141, West Java, Indonesia \\ ${ }^{2}$ Universitas Pendidikan Indonesia, Bandung 40154, West Java, Indonesia \\ * Corresponding Author. E-mail: raissa@student.upi.edu (Raissa)
}

\begin{tabular}{|l} 
ABSTRACT \\
This study aims to make a variety of Ladu product mixed with roasted peanuts and cashew \\
as additional nutritionns in the product. This research is conducted due to the fact that Ladu is \\
only familiar for local community (Garut resident) and not well known by wider community. \\
Morover, Ladu's flavor, shape and, variety are still made in original ones and not yet developed \\
in different variations. By conducting this research, it is expected that Ladu as a traditional food \\
can be an interesting food product for wider community. The method used in this study is a \\
qualitative method because it applied experimental methods. \\
Keywords: Product Variations; Ladu, Variations, Garut, Malambong. \\
First Received: \\
May $\mathbf{2 0 2 0}$ \\
Final Proof Received: \\
June $\mathbf{2 0 2 0}$
\end{tabular}




\section{Introduction}

In the tourism sector, contribution of culinary field is very influential because increasing number of innovative products and culinary variations as results of local people's creativity. The innovations and variations give different flavors and touches creating a food product with distinctive flavor that is able to arouse consumers' appetize and interst to the product.

Garut is one of regencies that has a lot of tourist attractions. Recently, many of them start to be known and visited either by local, domestic, or even foreign tourists. It offers not only natural destination but also art, cultural, and culinary destination.

The tourism sector has also become a gear in economic development for the local people.

Changes in the business world do not always bring a negative impact. One of the benefits is that there are new opportunities to create a variety of products. Variation is a strategy that can be used after we know the product or company positioning in consumers. Variations can be created based on company's strengths as well as differences with competitors.

Variations of local food products are currently less developed due to the lack of attention from the local people in certain areas to preserve and process the products. One of the examples is Ladu, a signature food from Malangbong- Garut. It has been around since 1930s. Ladu is a traditional snack made from glutinous rice flour, palm sugar, and coconut. In Garut, Ladu becomes a special food that is consumed when there are certain events. So, it is not always available and rarely consumed as a daily snack. However, there are still many people who do not know about this Garut traditional food, not only people outside Garut, but also the local people who live in Garut are not familiar with the food from their area. It is due to limited occations where people only serve it on special days. Besides, souvenir shops in Garut that sell Ladu are very rare only certain shops. In addition, the packaging is not too attractive and the flavor that can be found just original flavor without other variations.

\section{Literature Review}

\subsection{Tourism}

According to Pendit (2003: 20), tourism is a process of temporary departure of someone or more from their residences to other places outside the residences.

Meanwhile, according to Spillane (1987: 20 ), tourism is a journey from one place to another, temporary, carried out individually or in groups, as an effort to find a balance or harmony and happiness with the environment in social, cultural, natural, and scientific dimensions.

Based on Law of republic of Indonesia number 10 of 2009, tourism is various kinds of tour activities supported by various facilities and services provided by the community, enterpreneurs, Government and Regional Government.

So, it can be concluded that tourism is one of new industries that is able to increase economic growth quickly in terms of employment opportunities, income, living standards as well as in terms of activating other production sectors in the countries tourist destination.

\subsection{Culinary and Culinary Tourism}

Culinary is also called the art of cuisine. Culinary can be interpreted as a series of activities to produce healthy food with attractive appearance that starts from choosing quality food ingredients, preparing appropriate and safe processing techniques, and producing flavors according to the objectives (Soenardi, 2013, p. $6)$.

Moreover, Long defines culinary tourism as an intentional, exploratory participation in foodways from others, including participation of consumers, preparation and presentation of food items, cuisine, dining systems, or dining styles that are considered to have their own culinary systems. (Long. L, 2004, p. 21).

Based on the above definitions, it can be said that culinary is a series of activities carried out in order to produce a food that is healthy to consume, delicious, and attractive. On the other hand, culinary tourism is an activity undertaken to flavor a food or drink that can make an interesting impression for people who flavor it.

\subsection{Gastronomy}

According to Gilleisole (2001: 235) gastronomy or catering is the art or science of good food (good eating). A simpler explanation states that gastronomy is anything related to the enjoyment of food and drink. Other sources 
mention that gastronomy is a study of the relationship between culture and food. The relationshiop between Cultural and gastronomic is formed because gastronomy is a product of cultivation in agricultural activities so that the combination of colors, aromas, and flavors of a

food can be traced to its origin from the environment where its raw material is produced.

It can be concluded that gastronomy is a science which covers the mixing of food, food ingredients, manufacturing processes, phenomena, or symptoms behind food and beverage.

\subsection{Product Variations}

Changes in the business world do not always bring a negative impact. One of the benefits is that there are new opportunities to create a variety of products. Variation is a strategy that can be used after we know the product or company positioning in consumers. Variations can be created based on a company's strengths and differences with competitors.

According to Kotler (2009: 4) a product is anything that can be offered to market to get attention, be bought, be used or consumed and also satisfy desires as well as needs of consumers.

According to Alma (1992: 55) a product is a set of attributes both tangible and intangible. This includes the issues of color, price, variety, design, good name of the factory or company that is mostly not a consideration to buy a product.

Product variation is as a separate expert in a product brand that can be distinguished by size, price, appearance and characteristics (Kotler, 2009, p. 72). Meanwhile, according to Tjiptono (2008: 435), product variation is chosen if a company intends to utilize product flexibility as strategy to compete with other producers.

Based on the definitions above, it can be concluded that product is a thing or everything that can be offered to consumers whether tangible or not so that consumers can meet their desires and needs. Meanwhile, product variation is one way or an alternative that can be done by a company to improve performance of its products since variations in products can provide satisfaction for consumers.

\subsection{Product quality \\ Quality is totality of features and characteristics of products or services that}

depend on their ability to satisfy expressed or implied needs (Kotler and Keller, 2009, p. 143).

According to Marsum (2005: 15), the quality of food needs to pay attention on flavor (smell), consistency (stability), texture/ form/ shape (composition/shape/cut), nutritional content (nutritional content), visual appeal (attractiveness), aromatic appeal (aroma), and temperature (temperature).

Overall, product quality is a product condition which includes durability, apperances, and attractiveness of the product that can meet the desires of consumers as well as achieve a good quality of product values.

\subsection{Standard Recipe}

One determinant of a good quality food is the use of standardized recipes. Standard rescipe are written instructions containing various specific information about ingredients and tools that should be prepared to make a food. It also covers provisions for measures that have been put in place by the place of business (Suryadi, T., 2016, p. 4).

According to Amy Christine Brown (2014: 133). It is said that:

"Standardized recipe is one of the most important tools for assuring high quality food production. A standardized recipe is one that has been flavord and developed to meet the needs of the specific establishment and it also needs the skills of the food service personnel to produce it well".

From this statement, it can be assumed that the standard recipe is one of the most important factors to guarantee the quality of food products. The format of the recipe must be detail, has been tested to achieve the determination of the recipe, and requires the ability of a cook to follow established procedures so that the preparation and production process will be carried out properly.

\subsection{Product Packaging}

Well-designed packaging can build brand equity and drive sales. Packaging is the first part of the product that buyers face and able to attract buyers' interest. Packaging of a product is usually carried out by the manufacturer to be able to seize consumers' interest in purchasing goods.

According to Kotler \& Keller (2009: 27), packaging is activity of designing and producing containers or packages for a product. Packaging 
is activity of designing and producing package for products. Usually the main function of packaging is to maintain the product. However, now packaging has become an important factor in a marketing tool (Rangkuti, 2010, p. 132).

Packaging can be interpreted as a series or process carried out to provide a container or a product wrap so that the product can be distributed, sold, stored and used properly both for producers and consumers.

2.8. Marketing Strategy

Marketing strategy is one of marketing fields. It talks about patterns and systems arranged in such a way to be applied in overall marketing process.

According to Sofjan Assauri (2013: 15), marketing strategy is a series of goals and objectives, policies, and rules that give direction to the company's marketing from time to time, at each level including reference and allocation especially as a response to the company in dealing with changing environment and competition.

Meanwhile, according to Fandy Tjiptono (2000: 6), marketing strategy is a management structured to accelerate solution for marketing problems and make strategic decisions.

From some opinions according to experts, it can be concluded that marketing strategy is a set of goals arranged or designed in order to make marketing in a company runs well to potential customers.

\subsection{Ladu History}

In the 1930s the ladu was brought by Ibu Musti'ah to Malangbong District, Garut Regency. Ibu Musti'ah is known as an expert in making various traditional snacks such as Wajit Bodas, Angleng, and Ladu. However, at that time, the demand for Ladu was high and until now the production of the product still survives. Therefore, Ladu is famous as a traditional food that comes from Malangbong District and has become a souvenir of the region. Malangbong Ladu production has been done by three generations and now run by the grandson of Mrs. Musti'ah.

There are two point of views regarding the origin name of Ladu. First, Ladu was once made in an area near a mountain called Mount Ladu. Meanwhile, the second opinion claims that Sundanese people know the word Ladu from the name "Cau Ladu" which is ripe or ripe banana. In other words, Ladu means cooked or cooked food. Therefore, considering the process of making Ladu which is a mixing of cooked ingredients, it is named as Ladu. (MIK Indonesian Gastronomy, 2019, website, can be accessed

via http://gastronomiindonesia.mik.upi.edu/?P= 69)

\section{Materials and Methods}

The method used in this study is qualitative approach because it applied experimental research methods.

The object of this research is variation of Ladu products mixed with roasted peanuts and roasted cashews as additional nutritions. Besides, some natural food dyes are also added to provide new variations of Ladu for consumers.

The subject of the research is analysis of the experimental research products on one of the types of traditional food preparations typical of Malangbong-Garut which is varied with roasted peanuts and roasted cashews. The subject was also said to be an independent variable. The subject for assessing this study includes supervisor and researcher himself.

\section{Results and Discussion}

\subsection{Experimental Research Results}

Before discovering variations of recipe in the experimental research, the author makes an experiment to determine the recipe that matches the recipe first as follows:

Table 1. Results of Experiment Variations in Combined Products

\begin{tabular}{|c|c|c|c|}
\hline \multicolumn{4}{|c|}{ Trial Variation Experiment } \\
\hline No. & $\begin{array}{l}\text { Experiment } 1 \\
\text { (original with } \\
\text { the addition of } \\
\text { peanuts and } \\
\text { cashews) }\end{array}$ & Trial 2 & $\begin{array}{c}\text { Experime } \\
\text { nt } 3 \\
\text { (addition } \\
\text { of natural } \\
\text { coloring } \\
\text { of dragon } \\
\text { fruit and } \\
\text { pandan } \\
\text { leaves) }\end{array}$ \\
\hline 1 & $\begin{array}{lr}63 \mathrm{gr} & \text { White } \\
\text { Glutinous } & \text { Rice } \\
\text { Flour } & \end{array}$ & $\begin{array}{l}\text { 63gr } \quad \text { White } \\
\text { Glutinous } \\
\text { Flour }\end{array}$ & $\begin{array}{l}\text { 63gr } \\
\text { White } \\
\text { Glutinous } \\
\text { Rice Flour }\end{array}$ \\
\hline 2 & $\begin{array}{l}50 \mathrm{gr} \quad \text { Grated } \\
\text { Coconut }\end{array}$ & $\begin{array}{l}35 \mathrm{gr} \quad \text { Grated } \\
\text { Coconut }\end{array}$ & $\begin{array}{l}15 \mathrm{gr} \\
\text { Grated } \\
\text { Coconut }\end{array}$ \\
\hline 3 & $\begin{array}{l}50 \mathrm{gr} \quad \text { Brown } \\
\text { Sugar }\end{array}$ & $\begin{array}{l}\text { 50gr } \quad \text { Brown } \\
\text { Sugar }\end{array}$ & $\begin{array}{l}50 g r \\
\text { Brown } \\
\text { Sugar }\end{array}$ \\
\hline 4 & $\begin{array}{l}75 \mathrm{ml} \text { coconut } \\
\text { milk }\end{array}$ & $\begin{array}{l}80 \mathrm{ml} \text { coconut } \\
\text { milk }\end{array}$ & $\begin{array}{l}100 \mathrm{ml} \\
\text { coconut } \\
\text { milk }\end{array}$ \\
\hline
\end{tabular}




\begin{tabular}{|c|c|c|c|}
\hline \multicolumn{4}{|c|}{ Trial Variation Experiment } \\
\hline No. & $\begin{array}{l}\text { Experiment } 1 \\
\text { (original with } \\
\text { the addition of } \\
\text { peanuts and } \\
\text { cashews) }\end{array}$ & Trial 2 & $\begin{array}{c}\text { Experime } \\
\text { nt } 3 \\
\text { (addition } \\
\text { of natural } \\
\text { coloring } \\
\text { of dragon } \\
\text { fruit and } \\
\text { pandan } \\
\text { leaves) }\end{array}$ \\
\hline 5 & $0.75 \mathrm{gr} \mathrm{Salt}$ & $0.75 \mathrm{gr}$ Salt & $\begin{array}{l}0.75 \mathrm{gr} \\
\text { Salt }\end{array}$ \\
\hline 6 & $\begin{array}{l}\text { 5gr Peanuts \& } \\
\text { Cashew }\end{array}$ & $\begin{array}{l}\text { 10gr Peanuts \& } \\
\text { Cashew }\end{array}$ & $\begin{array}{l}15 \mathrm{gr} \\
\text { Peanuts \& } \\
\text { Cashew }\end{array}$ \\
\hline 7 & & & $\begin{array}{l}20 \mathrm{gr} \\
\text { Pandan } \\
\text { Leaf } \\
\text { Water }\end{array}$ \\
\hline 8 & & & $\begin{array}{l}20 \mathrm{gr} \\
\text { Dragon } \\
\text { Fruit }\end{array}$ \\
\hline
\end{tabular}

Results of the experiments showed that the researchers have done following include prescription standards, shelf life testing, nutritional value, and packaging design. These variations in Ladu products are treated with a comparison of three sample recipe formulations. The following three samples have different formulations, namely:

a. Variation of Ladu Products (VPL 1)

50 grams of Grated Coconut, $75 \mathrm{ml}$ of Coconut Milk, 5 grams of Peanuts, 5 grams of Cashew Nuts, 10 grams of dragon fruit extract and 10 grams of pandan leaf extract.

b. Variation of Ladu Products (VPL 2)

35 grams of Grated Coconut, $80 \mathrm{ml}$ of Coconut Milk, 10 grams of Peanuts, 10 grams of Cashew Nuts, 15 grams of dragon fruit extract and 15 grams of pandan leaf extract.

c. Variation of Ladu Products (VPL 3)

15 grams of Grated Coconut, $100 \mathrm{ml}$ of Coconut Milk, 15 grams of Peanuts, 15 grams of Cashew Nuts, 20 grams of dragon fruit extract and 20 grams of pandan leaf extract.

Out of the three recipes using the organoleptic test approach, prescription 3 was determined for the continuation of the product in the variation of the experimental product conducted by the researcher as explained by the following points.

\subsection{Recipe Formulation}

Table 2. Recipes for Variation in Combined Products (VPL 1)

\begin{tabular}{lcc}
\hline \multicolumn{1}{c}{ Material } & total & Unit \\
\hline White & 63 & Gram \\
Glutinous Rice & & \\
Flour & & \\
Grated coconut & 50 & Gram \\
Brown sugar & 50 & Gram \\
Coconut milk & 75 & Ml \\
Salt & 0.75 & Gram \\
Peanuts & 5 & Gram \\
Cashew nut & 5 & Gram \\
Dragon fruit & 20 & Gram \\
Pandan leaves & 20 & Gram
\end{tabular}

Source: Data processed, May 2020

Table 3. Recipes for Variation in Combined Products (VPL 2)

\begin{tabular}{lcc}
\hline \multicolumn{1}{c}{ Material } & total & Unit \\
\hline White Glutinous & 63 & Gram \\
Rice Flour & & \\
Grated coconut & 35 & Gram \\
Brown sugar & 50 & Gram \\
Coconut milk & 80 & Ml \\
Salt & 0.75 & Gram \\
Peanuts & 10 & Gram \\
Cashew nut & 10 & Gram \\
Dragon fruit & 20 & Gram \\
Pandan leaves & 20 & Gram \\
\hline
\end{tabular}

Source: Data processed, May 2020

Table 4. Recipes for Variation in Combined Products (VPL 3)

\begin{tabular}{lcc}
\hline \multicolumn{1}{c}{ Material } & Total & Unit \\
\hline White Glutinous & 63 & Gram \\
Rice Flour & & \\
Grated coconut & 15 & Gram \\
Brown sugar & 50 & Gram \\
Coconut milk & 100 & Ml \\
Salt & 0.75 & Gram \\
Peanuts & 15 & Gram \\
Cashew nut & 25 & Gram \\
Dragon fruit & 20 & Gram \\
Pandan leaves & 20 & Gram \\
\hline
\end{tabular}

Source: Data processed, May 2020 


\subsection{Overview of Research Objects}

Researchers conducted a comparison test between variations in product recipe based on product quality in order to be able to carry out organoleptic tests on three product samples. It used a scale rating 1-5 with a description of value: (1) Very Dislike, (2) Dislike, (3) Fair Like, (4) Like and (5) Really Like.

\subsubsection{Organoleptic Characteristics Research by testing at five \\ Concentrations using five assessment} characteristics including color, flavor, aroma, texture, and packaging.

a. Color Characteristics

Table 5. Values Against Color Characteristics

\begin{tabular}{cc}
\hline \multicolumn{2}{c}{ Color } \\
\hline Treatment & Score \\
\hline VPL 1 & 3.0 \\
VPL 2 & 3,2 \\
VPL 3 & 3,7 \\
\hline
\end{tabular}

Table 5 shows different color characteristics in the three samples tested by the researchers. It can be concluded that the product with the greatest value in VPL 3 is a ratio of 15 grams of Grated Coconut, $100 \mathrm{ml}$ of Coconut Milk, 15 grams of Peanuts, 15 grams of Cashew Nuts, 20 grams of extract dragon fruit, 20 grams of pandan leaf extract with a value of 3.7 and the smallest value on VPL 1 with a ratio of 50 grams of Grated Coconut, $75 \mathrm{ml}$ of Coconut Milk, 5 grams of Peanuts, 5 grams of Cashew Nuts, 10 grams of dragon fruit extract and 10 grams of pandan leaf extract with a value of 3.0.

b. Flavor Characteristics

Table 6. Value of Flavor Characteristics

\begin{tabular}{cc}
\hline \multicolumn{3}{c}{ Flavor } \\
\hline Treatment & Score \\
\hline VPL 1 & 3,2 \\
VPL 2 & 2.5 \\
VPL 3 & 4.0 \\
\hline
\end{tabular}

Source: Data processed, May 2020

Table 6 shows differences in flavor characteristics in the three samples tested. It can be concluded that the product with the highest value in VPL 3 gets a value of 4.0. c. Aroma Characteristics

Table 7. Value of Aroma Characteristics

\begin{tabular}{cc}
\hline \multicolumn{2}{c}{ Aroma } \\
\hline Treatment & Score \\
\hline VPL 1 & 3.5 \\
VPL 2 & 3.5 \\
VPL 3 & 3,7 \\
\hline
\end{tabular}

Source: Data processed, May 2020

Table 7 shows the different aroma characteristics in the three samples tested, so it can be concluded that the product with the highest value in VPL 3 gets a value of 3.7. Based on the results, the alleged aroma researchers owned by VPL 3 are slightly stronger than the other samples.

d. Texture Characteristics

Table 8. Value of Texture Characteristics

\begin{tabular}{cc}
\hline \multicolumn{2}{c}{ Texture } \\
\hline Treatment & Score \\
\hline VPL 1 & 2,9 \\
VPL 2 & 3,2 \\
VPL 3 & 4.2 \\
\hline
\end{tabular}

Source: Data processed, May 2020

Table 8 shows the differences in texture characteristics in the three samples tested. It can be concluded that the product with the greatest value in VPL 3 with a value of 4.2 because the composition of the material is right and in accordance so that the texture owned by the ladu in VPL 3 feels more good compared to the other samples.

e. Packaging Characteristics

Table 9. Value of Packaging Characteristics

\begin{tabular}{cc}
\hline \multicolumn{2}{c}{ The packaging } \\
\hline Treatment & Score \\
\hline VPL 1 & 4.5 \\
VPL 2 & 4.5 \\
VPL 3 & 4.5 \\
\hline
\end{tabular}

Source: Data processed, June 2020

Table 9 shows that testing of these three samples uses the same packaging so that the researcher gives the same value with the value of 4.5. Ladu packaging generally only uses mica plastic or it is only wrapped in paper. However, the new variation of Ladu product packaging is more interesting and practical so that the 
researchers conclude that the packaging is acceptable.

\subsubsection{Overall Characteristics of Organoleptic Tests}

This test shows preferential level assessed by researchers for all variations of Ladu products. The selected product is a variation of VPL 3 recipes with a total value of 20.4. The following are the results of the organoleptic test values in the table below:

Table 10. Recapitulation of Variation in Ladu Product Recipe

\begin{tabular}{|c|c|c|c|c|c|c|c|}
\hline \multirow[b]{2}{*}{ No } & \multirow[b]{2}{*}{$\begin{array}{c}\text { Compa } \\
\text { rison }\end{array}$} & \multicolumn{5}{|c|}{ Score } & \multirow[b]{2}{*}{$\begin{array}{l}\text { Tota } \\
1\end{array}$} \\
\hline & & $\begin{array}{l}\text { Col } \\
\text { or }\end{array}$ & $\begin{array}{l}\text { flav } \\
\text { or }\end{array}$ & $\begin{array}{c}\text { Aro } \\
\text { ma }\end{array}$ & $\begin{array}{l}\text { Textur } \\
\text { e }\end{array}$ & $\begin{array}{l}\text { The } \\
\text { packa } \\
\text { ging }\end{array}$ & \\
\hline 1 & VPL 1 & 3.0 & 3,2 & 3.5 & 2,9 & 4.5 & $\begin{array}{c}17 . \\
1\end{array}$ \\
\hline 2 & VPL 2 & 3,2 & 2.5 & 3.5 & 3,2 & 4.5 & $\begin{array}{c}16 . \\
9\end{array}$ \\
\hline 3 & VPL 3 & 3,7 & 4.0 & 3,7 & 4.5 & 4.5 & $\begin{array}{c}20 . \\
4\end{array}$ \\
\hline
\end{tabular}

Source: Data processed, June 2020

Table 10 shows the most preferred product results from three different recipe variations which is VPL 3 with a total value of 20.4 .

\subsection{Save Durability}

The shelf life test for Ladu variants is carried out by subjective observations in two different temperatures. The first endurance test was carried out at room temperature $28-29^{\circ} \mathrm{C}$ and the second shelf life test was carried out at the temperature of the chiller or refrigerator 0$18^{\circ} \mathrm{C}$. Several aspects observed by the researchers include color, texture, aroma, and flavor. Following are the observations of shelf life test from variants of Ladu products:

Table 11. Durability Save at Room Temperature

\begin{tabular}{clllllll}
\hline \multirow{2}{*}{$\begin{array}{c}\text { Variati on } \\
\text { of }\end{array}$} & Observation & \multicolumn{7}{c}{ Days to- } \\
Ladu & 2 & 3 & 4 & 5 & 6 & 7 \\
\cline { 2 - 8 } Produc & a. Color & 5 & 5 & 3 & 1 & 1 & 1 \\
ts & b. Rasa & 5 & 3 & 2 & 1 & 1 & 1 \\
$($ VPL) & c. Texture & 5 & 3 & 2 & 2 & 1 & 1 \\
& d. Aroma & 5 & 3 & 3 & 2 & 1 & 1 \\
\hline
\end{tabular}

Source: Data processed, May 2020
Table 12. Durability to Store at Temperature Ciller

\begin{tabular}{clllllll}
\hline Variati & Observation & \multicolumn{6}{c}{ Days to- } \\
\cline { 3 - 8 } on of & & 2 & 3 & 4 & 5 & 6 & 7 \\
\cline { 2 - 7 } Ladu & a. Color & 5 & 5 & 3 & 1 & 1 & 1 \\
Produc & b. Flavor & 5 & 3 & 2 & 1 & 1 & 1 \\
ts & c. Texture & 5 & 3 & 2 & 2 & 1 & 1 \\
$($ VPL) & d. Aroma & 5 & 3 & 3 & 2 & 1 & 1 \\
\hline
\end{tabular}

Source: Data processed, May 2020

Table 11 and table 12 explain that the value of 5 shows the highest value which means that the product is in a normal and a good condition. If the value decreases, it means the quality of the product reduced.

4.5. Calculation of Nutrition Vary for Variation of Combined Products

Table 13. Nutrition Content According to DKBM

\begin{tabular}{|c|c|c|c|c|c|}
\hline \multirow{2}{*}{$\begin{array}{l}\text { Name } \\
\text { mater } \\
\text { ial Unit }\end{array}$} & Bydd & Energy & Fat & Protein & Carbohydrate \\
\hline & & cal & $\mathrm{g}$ & $\mathrm{g}$ & $\mathrm{g}$ \\
\hline $\begin{array}{c}\text { White } \\
\text { Glutin } \\
\text { ous } \\
\text { Rice } \\
\text { Flour }\end{array}$ & 100 & 361 & 0.80 & 7.40 & 78.40 \\
\hline $\begin{array}{l}\text { Grated } \\
\text { coconut }\end{array}$ & 53 & 359 & 34.70 & 3.40 & 14 \\
\hline $\begin{array}{l}\text { Brown } \\
\text { sugar }\end{array}$ & 100 & 368 & 0 & 0 & 95 \\
\hline $\begin{array}{l}\text { Coconut } \\
\text { milk }\end{array}$ & 100 & 122 & 2 & 2 & 7.60 \\
\hline Salt & 100 & 0 & 0 & 0 & 0 \\
\hline Peanuts & 100 & 533 & 40.8 & 25.3 & 21.1 \\
\hline $\begin{array}{c}\text { Cashew } \\
\text { nut }\end{array}$ & 100 & 562 & 49.60 & 21.20 & 23.60 \\
\hline $\begin{array}{c}\text { Dragon } \\
\text { fruit }\end{array}$ & 100 & 71 & 3.10 & 1.70 & 9,10 \\
\hline $\begin{array}{c}\text { Pandan } \\
\text { leaves }\end{array}$ & 100 & 0 & 0.58 & 3.15 & 10,92 \\
\hline
\end{tabular}

Source: Ministry of Health, 2005 
Table 14. Nutritional Value of Variation in Combined Product

\begin{tabular}{|c|c|c|c|c|c|}
\hline \multirow{2}{*}{$\begin{array}{l}\text { Name } \\
\text { mater ial } \\
\text { Unit }\end{array}$} & \multirow[t]{2}{*}{ Weight } & \multirow{2}{*}{$\begin{array}{c}\text { Energy } \\
\text { cal }\end{array}$} & \multirow{2}{*}{$\begin{array}{c}\text { Fat } \\
\mathrm{g}\end{array}$} & \multirow{2}{*}{$\begin{array}{c}\text { Protein } \\
\text { g }\end{array}$} & \multirow{2}{*}{$\begin{array}{l}\text { Carbohydrt } \\
\text { e } \\
\text { G }\end{array}$} \\
\hline & & & & & \\
\hline $\begin{array}{l}\text { White } \\
\text { Glutin } \\
\text { ous } \\
\text { Rice } \\
\text { Flour }\end{array}$ & $63 \mathrm{gr}$ & 361 & 0.80 & 7.40 & 78.4 \\
\hline $\begin{array}{l}\text { Grated } \\
\text { coconut }\end{array}$ & $15 \mathrm{gr}$ & 359 & $\begin{array}{c}34.7 \\
0\end{array}$ & 3.40 & 14 \\
\hline $\begin{array}{l}\text { Brown } \\
\text { sugar }\end{array}$ & $50 \mathrm{gr}$ & 368 & 0 & 0 & 95 \\
\hline $\begin{array}{l}\text { Coconut } \\
\text { milk }\end{array}$ & $\begin{array}{l}100 \\
\mathrm{ml}\end{array}$ & 122 & 2 & 2 & 7.60 \\
\hline Salt & $\begin{array}{l}0.75 \\
\mathrm{gr}\end{array}$ & 0 & 0 & 0 & 0 \\
\hline Peanuts & $15 \mathrm{gr}$ & 533 & 40.8 & 25.3 & 21.1 \\
\hline $\begin{array}{l}\text { Cashew } \\
\text { nut }\end{array}$ & $15 \mathrm{gr}$ & 562 & $\begin{array}{c}49.6 \\
0\end{array}$ & 21.20 & $\begin{array}{c}23.6 \\
0\end{array}$ \\
\hline $\begin{array}{l}\text { Dragon } \\
\text { fruit }\end{array}$ & $20 \mathrm{gr}$ & 71 & 3.10 & 1.70 & 9,10 \\
\hline $\begin{array}{l}\text { Pandan } \\
\text { leaves }\end{array}$ & $20 \mathrm{gr}$ & 0 & 0.58 & 3.15 & $\begin{array}{c}10,9 \\
2\end{array}$ \\
\hline Total of 6 & pcs & 2376 & $\begin{array}{c}131 . \\
5 \\
8\end{array}$ & 64,15 & $\begin{array}{c}259 . \\
72\end{array}$ \\
\hline Amount $\mathrm{p}$ & er $1 \mathrm{pcs}$ & 396 & $\begin{array}{c}21.9 \\
3 \\
\end{array}$ & 10,69 & $\begin{array}{c}43.2 \\
8 \\
\end{array}$ \\
\hline
\end{tabular}

Source: Data processed, May 2020.

$\begin{array}{ll}21.93 \times 9 \text { fat } & =197.37 \\ \text { Protein } 10.69 \times 4 & =42.76 \\ \text { Carbohydrates } 43.28 \times 4 & =173.12\end{array}$

Table 15. Nutrition Content Per 1 Pcs VPL (Variation of Ladu Products)

\begin{tabular}{cc}
\hline \multicolumn{2}{c}{ Nutritional Value } \\
\hline Energy & $396 \mathrm{cal}$ \\
Fat & $197.37 \mathrm{gr}$ \\
Protein & $42.76 \mathrm{gr}$ \\
Carbohydrate & $173.12 \mathrm{gr}$ \\
\hline
\end{tabular}

Source: Data processed, May 2020

Table 13 explains nutritional data for each VPL raw material per $100 \mathrm{gr}$ of raw materials needed according to the DKBM. Table 14 explains the total nutritional content of Ladu product variations in one recipe that makes 6 pcs of Ladu. Table15 explains the nutritional value of Ladu product variations in $1 \mathrm{pcs}$, there are 396 cal of energy, 197.37 grams of fat, 42.76 grams of protein and 173.12 grams of carbohydrate.

\subsection{Variation of Ladu Product Packaging}

The packaging used for variations of ladu products is paper and plastic labeled with a logo. The packaging was designed by the author to be more attractive and eye cacthing for consumers. Packaging images used in variations of Ladu products can be seen below:
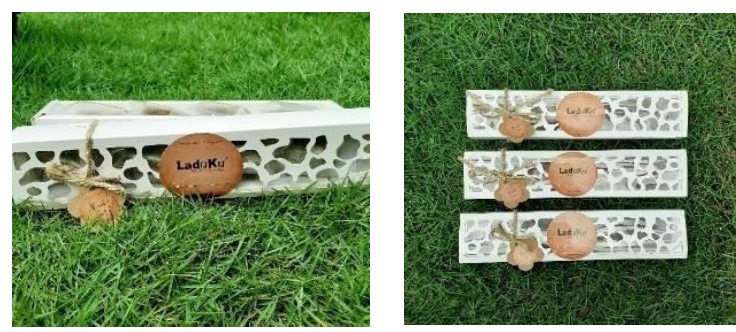

Figure 1. Variation Packaging of Ladu Products Source: Data processed, May 2020

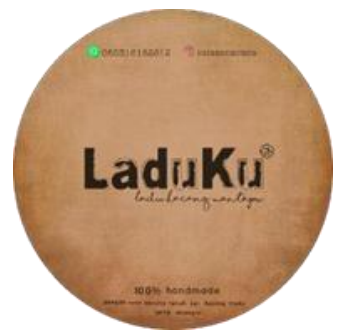

Figure 2. Logo Variation of Ladu Products Source: Data processed, May 2020

Figure 1 is an example of packaging for variations of Ladu products containing a 4 pcs Ladu. In figure 2 shows the name of the new variation product, LaduKu, with its logo originally designes by the reseachers. The packaging has covered standard requirements of packaging and labeling such as logo, composition, nutritional value, halal logo, expired and personal contacts.

\section{Conclusions}

Based on the observations made by the authors that have been explained in the previous chapter, variations of Ladu products mixed with additional ingredients have some differences and advantages from one product over the others. The advantage of Ladu variations is that it has different sensations when people eat it because it has been mixed with roasted peanuts and roasted cashews. In addition, it has an attractive 
color and an eye catching packaging.

There are some points that can be consluded related to the Variation of Ladu Products:

a. Product quality of variations of Ladu products.

After conducting a kitchen project and organoleptic tests in variations of Ladu products indicated by new color, flavor, aroma, texture, and packaging, the result shows that in terms of product quality VPL 3 recipe variation is the best prodcut where overall values is 20.4.

Meanwhile, the lowest product quality is in VPL 2 recipe variations which gets score of 16.9 .

Then, the researchers conducted a shelf life test in which the products were stored at room temperature and chiller temperature. After storing the endurance test, the results show that if stored at room temperature with a temperature of $28-29^{\circ} \mathrm{C}$, the products can last for 2-3 days. On the other hand, for Ladu products which are stored in a chiller with temperature of $0-18^{\circ} \mathrm{C}$, the products can last for a week.

b. Standard recipe of variations of Ladu products.

After doing the kitchen project, there are three different recipe variations as follows:

1) VPL 1 uses 50 grams of Grated Coconut, $75 \mathrm{ml}$ of Coconut Milk, 5 grams of Peanuts, 5 grams of Cashew Nuts, 10 grams of dragon fruit extract and 10 grams of pandan leaf extract.

2) VPL 2 uses 35 grams of Grated Coconut, $80 \mathrm{ml}$ of Coconut Milk, 10 grams of Peanuts, 10 grams of Cashew Nuts, 15 grams of dragon fruit extract and 15 grams of pandan leaf extract.

3) VPL 3 uses 15 grams of Grated Coconut, $100 \mathrm{ml}$ of Coconut Milk, 15 grams of Peanuts, 15 grams of Cashew Nuts, 20 grams of dragon fruit extract and 20 grams of pandan leaf extract.

The results of this study on three different recipe variations using assessment indicators in terms of color, flavor, aroma, texture, and packaging shows that the best product is variations of VPL 3 recipe with total value 20.4 while for variations in recipes VPL 2 gets the lower score with value of 16.9 .

c. Packaging that is owned by variations of Ladu products.

The packaging is made from thick paper so it is not easily damaged and labeled with a logo. The researchers named the variations of Ladu product as "LaduKu" which signifies the ownership, the researchers' property, and the property of anyone who later becomes the purchaser of this product. The packaging is designed in such a way in order to be attractive, beautiful, unique, simple, and not monotonous so that it would attracts consumers' interest to buy the product. In its packaging, there are some valuable information about the product including logo, table of nutritional value, ingredients composition, expired product, and production information.

b. Marketing strategy in variations of Ladu products.

There are two marketing strategies used to promote the products: (1) promoting it through social media networks that are personally owned by the authors and specifically created by the authors (2) and promoting it directly to friends and family. The variations of Ladu product is a breakthrough since the author makes variations of Ladu by adding roasted peanuts and cashews. In addition, pandan leaf and dragon fruit extracts are also added to the product so that it may attract potential consumers' interest to buy the products. Morover, by creating variations of Ladu product, it highlights potential of local products to be a great source of income as long as the products apply innovation and modification in terms of packaging, marketing, and flavor.

\section{References}

A.W Marsum. 2005. Restoran dan Segala Permaslahannya, Edisi IV. Yogyakarta: Andi.

Alma, Buchari. 1992. Manajemen Pemasaran dan Pemasaran Jasa. Bandung: Alfabeta.

Assauri, Sofjan. (2013). Manajemen Pemasaran. Jakarta: Rajawali Press

Brown, Amy. (2014). Understanding Food Principles and Preparation. USA: Cengage Learning.

Gilleisole. (2001). European Gastronomy Into 21 Century. Oxford: Oxford Univesity.

Kotler, K. (2009). Manajemen Pemasaran

1. Edisi ketiga belas. Jakarta: Erlangga Long, L. (2004). Culinary Tourism. Lexington, KY: The University Press of Kentucky.

MIK Gastronomi Indonesia - Ladu Khas Malangbong Garut (2019, 10-9-2019). Diakses 10-12-2019,2019, melalui 
http://gastronimiindonesia.

mik.upi.edu/?p=69

Pemerintah Indonesia. (2009). Undang- Undang Nomor 10 Tahun 2009 tentang Kepariwisataan. Lembaran RI Tahun 2009 No. 11. Jakarta: Sekretariat Negara.

Pendit, Nyoman S. (2003). Ilmu Pariwisata Sebuah Pengantar Perdana. Jakarta: Pradnya Paramita.

Spillane, J.J. (1987). Pariwisata Indonesia Sejarah dan Prospeknya Yogyakarta: Kanisius. 150 halaman

Soenardi, Tuti dan Tim Yayasan Gizi Kuliner Jakarta. (2013). Teori Dasar Kuliner. Jakarta: PT. Gramedia Pustaka Utama.
Suryadi, T. (2016). Penerapan Standar Resep di Dakken Coffee and Steak Bandung. [Tugas Akhir]. Bandung: Sekolah Tinggi Pariwisata Bandung

Tjiptono, Fandy. (2000). Manajemen Jasa, Edisi Kedua. Yogyakarta: Andi Offset.

Tjiptono, Fandy. (2008). Strategi Pemasaran, Edisi tiga. Yogyakarta: Andi

Rangkuti, F. (2010). Perbedaan Mendasar Loyalitas Merek dengan Loyalitas Pelanggan. Diakses pada 9 Desember 2019 dari www.FraiMarketingCommunity/index. php.htm 